\title{
Biomonitoring Study - Toxic Elements in Human Blood
}

\author{
J. Valachova*, O. Osina, T. Vasicko, L. Musak and J. Buchancova
}

Clinic of Occupational Medicine and Toxicology, Comenius University, Jessenius Faculty of Medicine and University Hospital, Martin, Slovakia

\begin{abstract}
The content of toxic heavy metals ( $\mathrm{As}, \mathrm{Cd}, \mathrm{Cr}, \mathrm{Hg}$, and $\mathrm{Pb}$ ) in blood depends on locality, industry and social status of habitants. We studied this determination in detail in 1994.The blood of the young healthy blood donors without any metal exposure was analyzed by the atomic absorption spectrophotometry. The results were used as the reference values of the average non-exposed population. These results did not differ from those gained in other European countries. There is no regular human bio- monitoring in Slovakia but there are monitors practiced in neighbouring countries like Czech Republic or Germany. We could suppose the level of exposure in our region from these results and from literature. After 20 years the industry changed and the new technologies bring better quality of environment. It is not very appropriate to compare the results of samples which were analyzed in this time with old table values. But until this study we did not have newer data. We aimed to prepare the new bio-monitoring procedures containing recent data obtained by an inductively coupled plasma-mass spectrometry as new reference values for measurements evaluation.
\end{abstract}

Keywords: Arsenic, Cadmium, Chromium, Heavy metals, Lead, Mercury, Occupational exposure, Toxicity.

\section{INTRODUCTION}

Heavy metals are environmental pollutants and their content in blood depends on a number of factors. The percentage of these toxic elements can be assessed by monitoring the blood concentration of the exposed humans. Our aim is to protect the general population, children and workers, from potentially negative effects of exposure to toxic heavy metals like lead $(\mathrm{Pb})$, arsenic (As), chromium $(\mathrm{Cr})$, cadmium $(\mathrm{Cd})$ and mercury $(\mathrm{Hg})$. The most reliable biomarker of current elements exposure is determination of their concentration in blood. We studied this measurement in detail in 1994[1]. For population surveys and for occupational monitoring programs this invasive method was used. We analyzed blood of the healthy blood donors without any metal exposure. Blood (90\% water, $10 \%$ red / white blood cells / platelets, proteins and inorganic salts) is a useful medium for measuring exposure (especially of $\mathrm{Pb}, \mathrm{Hg}$ and $\mathrm{Cd}$ ) - these analytes become associated with haemoglobin so they are much higher in whole blood. Several analytical procedures were applied to quantitate elements in blood. We used atomic absorption spectrometry (AAS) in 1994. The results were applied as the reference values of the average non-exposed population. These results did not differ from those gained in other European countries. There was no regular human bio - monitoring in Slovakia but there were monitors used in neighbouring countries such as Czech Republic or Germany [2]. We could assume that the level of exposure in our area was similar from these results

*Address correspondence to this author at the Clinic of Occupational Medicine and Toxicology, Comenius University, Jessenius Faculty of Medicine and University Hospital, Martin, Slovakia; Tel: +421434203782; Fax: +421908964701; E-mail: valachova@jfmed.uniba.sk and from literature. After 20 years, the industry changed and recent modern technology brings better quality to the country side. We cannot compare the recent concentrations to the old results. The aim of this new work was to measure the concentration of toxic heavy metals in the blood of an unexposed group and to compare it with the results of a similar group from the year 1994. The levels of mentioned metals will likely be reduced. We prepared the new human monitoring containing new data obtained by an inductively coupled plasma-mass spectrometry (ICP-MS) as a recent reference value for measurement evaluations.

\section{MATERIAL AND METHODS}

The samples were prepared from $5 \mathrm{ml}$ of heparinized blood. All samples were stored at $5{ }^{\circ} \mathrm{C}$ and analysed within couple of days. They were diluted (1:4 by volume) with Triton X-100. The stock standard solutions from Merck at concentrations $1000 \mathrm{mg} . \mathrm{l}^{-1}$ were used for preparationin working standards with the known amounts. The atomic absorption spectrophotometer (AAS Spectr. AA 30 P, GTA - 96) from company Varian was used for $\mathrm{Cr}, \mathrm{Cd}$, and $\mathrm{Pb}$ with detection limit of sample $0.003 \mu$ mol. $1^{-1}$. We worked with the single-element capacity lamp for each element. All conditions are presented in Table $\mathbf{1}$.

For the determination in 2014 ICP-MS was chosen over the previously used AAS or other methods. Our laboratory received new ICP-MSThermo Fischer XSeries 2. Generally both methods are for determination of elements. ICP-MS is a newer method with lower detection limit. For ICP-MS we used the value of $5 \mathrm{ml}$ of morning blood collected with heparin into $10-\mathrm{ml}$ polyethylene centrifuge tubes. The samples were stored at $-20{ }^{\circ} \mathrm{C}$ until analysis. A blank for 
Table 1. Measurement conditions and technical parameters of AA 30P for elements.

\begin{tabular}{|c|c|c|c|c|c|}
\hline Analysed element in blood & As & Cd & Cr & Pb \\
\hline \hline Decomposition sample & VGA & GTA & GTA -96 & VGA & GTA \\
\hline Wave length (mA) & 193.7 & 228.8 & 357.9 & 253.7 \\
\hline Spectral slit width (nm) & 0.2 & 0.5 & 0.2 & 0.5 & 4 \\
\hline Current Cathode Lamp (mA) & 10 & 5 & 7 & 5 \\
\hline Atomisation Temperature $\left({ }^{\circ} \mathrm{C}\right)$ & by air-acetylene & 2500 & 2600 & by air-acetylene & 2600 \\
\hline
\end{tabular}

Table 2. Optimal operate parameters ICP-MS.

\begin{tabular}{|c|c|}
\hline ICP-MS & Thermo Fischer XSeries 2 \\
\hline \hline RF Generator forward power, W & 1400 \\
\hline Gas flow in nebuliser, $1 . \mathrm{min}^{-1}$ & 0.91 \\
\hline Gas flow in plasma, $1 . \mathrm{min}^{-1}$ & 0.85 \\
\hline Gas flow of cooling gas, $1 . \mathrm{min}^{-1}$ & 13 \\
\hline Gas flow rates H2/He, ml.min ${ }^{-1}$ for As, $\mathrm{Cr}$ & 7.5 \\
\hline Isotopes & ${ }^{75} \mathrm{As},{ }^{111} \mathrm{Cd},{ }^{52} \mathrm{Cr},{ }^{202} \mathrm{Hg},{ }^{208} \mathrm{~Pb},{ }^{71} \mathrm{Ga},{ }^{103} \mathrm{Rh},{ }^{209} \mathrm{Bi},{ }^{209} \mathrm{In}$ \\
\hline Replicate time, $\mathrm{ms}$ & 600 \\
\hline Resolution mode & $\mathrm{Normal} \mathrm{and} \mathrm{CCT}$ \\
\hline Dwell time, ms & 30 for each isotopes \\
\hline Number of replicates & 3 \\
\hline Sample read delay, s / Wash-out time, s & $60 / 40$ \\
\hline
\end{tabular}

ICP-MS (3\% 2-propanol for gas chromatography (GC); 0,1 $\% \mathrm{HNO}_{3}$ OPTIMA Grade for spectroscopy; $0,1 \%$ solution Triton ${ }^{\circledR}$ X-100 for GC in ultrapure water) was used for blood samples, reference materials and for working standards 2,5 , 10 and $20 \mu \mathrm{g} . \mathrm{l}^{-1}$. Internal standard was a mixture solution of $\mathrm{Ga}$, In, Bi and $\mathrm{Rh} 10 \mathrm{ppb}$. Reference materials (Seronorm ${ }^{\mathrm{TM}}$ Trace Elements Whole Blood, Level 1 and 2) are produced from human blood. These were reconstituted with $3 \mathrm{ml}$ of deionized water according to producer's instructions. Internal control materials were prepared same as samples by mixing blanc with Seronorm Trace Elements Whole Blood, Levels 1 and 2 in ratio 1:49. All human blood samples were without donors names. All participants gave written informed consent. Clinicians were asked for the assessment of metal exposure. Table 2 contents the major optimal conditions of ICP-MS.

Statistical data like arithmetic average values (x) and standard deviations $( \pm$ SD) or standard error $( \pm$ SE) were calculated by statistical methods through a computer program MS EXCEL.

\section{RESULTS}

All basic information of participants are in Table 3. All samples in 2014 were collected from 41 volunteers (22 men and 19 women, age range 23 to 39 years) living in the middle Slovakia.

The concentration of heavy metals in blood shows a significant declining trend after a long term - twenty years (Table 4). The levels of investigated subjects correspond with the values obtained in others around industrial countries [3]. The potential risk of these toxic metals needs further monitoring and control. The obtained levels of $\mathrm{Hg}$ are located in the lower part of reference values. Being a continental country with a low consumption of fish and seafood, the burden of lead in this population is continuously decreasing. The main source of environmental exposure has been the use of leaded gasoline in past. Its phase-out has led to decreased lead concentrations in the general population.

Levels of $\mathrm{Cd}$ and $\mathrm{Pb}$ are associated with smoking (Table 5). We observed significantly increased values of blood cadmium in smokers in 1994 and in 2014, as well. Authors stated that any environmental study of heavy metal concentrations is not present. Regular controls of environment like contents of pollutants in atmosphere or water are done by regional public health authority. This authority controls and provides quality environment for general population. These human samples provide people leaving in good and clean living conditions. 
Table 3. Basic data of adults.

\begin{tabular}{|c|c|c|}
\hline Sampling in Year & $\mathbf{1 9 9 4}$ & $\mathbf{2 0 1 4}$ \\
\hline \hline Number of subjects & 73 & $35.00 \pm 4.62$ \\
\hline Average age (years \pm SD) & $38.46 \pm 8.50$ & $23-39$ \\
\hline Range (years) & $22-65$ & $78.31 \pm 18.23$ \\
\hline Average weight (kg士SD) & $85.27 \pm 13.07$ & $47-120$ \\
\hline Range (kg) & $60-128$ & 18 \\
\hline Number of smokers & 45 & 43.90 \\
\hline$\%$ smokers & 61.64 & \\
\hline
\end{tabular}

Table 4. Concentrations of heavy metals in blood $\left(\mu \mathrm{g} . \mathrm{I}^{-1}=\mathrm{ppb} ; \mathrm{x} \pm \mathrm{SE}\right)$.

\begin{tabular}{|c|c|c|c|}
\hline Sampling in Year & $\mathbf{1 9 9 4}(\mathbf{n}=\mathbf{7 3})$ & $\mathbf{2 0 1 4}(\mathbf{n}=\mathbf{4 1})$ & Stat. signific. $(\mathbf{p})$ \\
\hline \hline $\mathrm{As}\left(\mu \mathrm{g} . \mathrm{l}^{-1} \pm \mathrm{SE}\right)$ & $5.02 \pm 0.18$ & $3.36 \pm 0.38$ & $\mathrm{p}<0,001$ \\
\hline $\mathrm{Cd}\left(\mu \mathrm{g} . \mathrm{l}^{-1} \pm \mathrm{SE}\right)$ & $2.20 \pm 0.001$ & $0.73 \pm 0.53$ & $\mathrm{p}<0,01$ \\
\hline $\mathrm{Cr}\left(\mu \mathrm{g} . \mathrm{l}^{-1} \pm \mathrm{SE}\right)$ & $2.50 \pm 0.003$ & $0.67 \pm 0.06$ & $\mathrm{p}<0,001$ \\
\hline $\mathrm{Hg}\left(\mu \mathrm{g} . \mathrm{l}^{-1} \pm \mathrm{SE}\right)$ & $4.01 \pm 0.02$ & $1.83 \pm 0.19$ & $\mathrm{p}<0,001$ \\
\hline $\mathrm{Pb}\left(\mu \mathrm{g} . \mathrm{l}^{-1} \pm \mathrm{SE}\right)$ & $93.24 \pm 0.02$ & $45.68 \pm 3.69$ & $\mathrm{p}<0,001$ \\
\hline
\end{tabular}

Table 5. Concentrations of heavy metals in blood $\left(\mu \mathrm{g} . \mathrm{I}^{-1}=\mathrm{ppb} ; \mathrm{x} \pm \mathrm{SE}\right)$.

\begin{tabular}{|c|c|c|c|c|c|}
\hline Year & \multicolumn{2}{|c|}{ 1994 (n=73) } & \multicolumn{2}{c|}{ 2014 (n=41) } & Stat. Significance (p) \\
\hline \hline Parameter & Nonsmokers & Smoker & Nonsmokers & Smoker & \\
\hline Number of smokers & 28 & 45 & 23 & 18 & \\
\hline$\%$ from group & 38 & 62 & 56 & 44 & $\mathrm{p}<0,001$ for 2014 \\
\hline $\mathrm{Cd}\left(\mu \mathrm{g} .1^{-1} \pm \mathrm{SE}\right)$ & $1.65 \pm 0.001$ & $2.56 \pm 0.02$ & $0.262 \pm 0.04$ & $1.65 \pm 0.27$ & $\mathrm{p}<0,001$ for 2014 \\
\hline $\mathrm{Pb}\left(\mu \mathrm{g} .1^{-1} \pm \mathrm{SE}\right)$ & without results & without results & $33.15 \pm 2.09$ & $61.70 \pm 5.62$ & \\
\hline
\end{tabular}

\section{DISCUSSION AND CONCLUSION}

In most industrialized countries (like the USA and Great Britain) improvements in working conditions and actions taken to minimize the environmental exposure to heavy metals have led to a substantial reduction of their concentrations in blood in both workers and in the general population [4]. The levels of heavy metals in blood with a significant declining trend are described in other studies. In Italy, a study from 2002 [5] reported mean values for lead in blood of $45.1 \mu \mathrm{g} .1^{-1}$ for males and $30.6 \mu \mathrm{g} .1^{-1}$ for females compared with median values of $86 \mu \mathrm{g} . .^{-1}$ for males and 53.5 $\mu \mathrm{g} .1^{-1}$ for females between 1992 and 1996.

Regular clinical analysis of toxic elements are important because people can be exposed to significant levels of these most common elements from country side and from production facilities as well. We can control high level exposure to these elements by monitoring these toxic concentrations and can take measures to stop the prolonged harmful effects. Concentrations of $\mathrm{Cd}$ and $\mathrm{Pb}$ in blood of adult population have been significantly influenced by smoking habits. We observed significant and slow descending trend for the blood cadmium level in nonsmokers. The levels of mercury in the blood of adults are in good agreement with the data obtained in other European countries.

\section{CONFLICT OF INTEREST}

The authors confirm that this article content has no conflict of interest.

\section{ACKNOWLEDGEMENTS}

This work is supported with project "CARCINOGENIC AND TOXIC METALS IN WORKING ENVIRONMENT". 


\section{REFERENCES}

[1] Buchancová, J.; Knizková, M.; Hýllová, D.; Vrlík, M.; Mesko, D.; Klimentová, G.; Gáliková, E. Content of the selected trace elements ( $\mathrm{Al}, \mathrm{As}, \mathrm{Cd}, \mathrm{Cu}, \mathrm{Fe}, \mathrm{Hg}, \mathrm{Mn}, \mathrm{Ni}, \mathrm{Pb}, \mathrm{Zn}$ ) in blood, urine and hair of blood donors without occupational exposure to these metals. Cent Eur J Public Health, 1994, 2(2), 82-87.

[2] Cejchanová, M.; Wranová, K.; Spevácková, V.; Krsková, A.; Smíd, J.; Cerná, M. Human bio-monitoring study--toxic elements in blood of women. Cent Eur J Public Health, 2012, 20(2), 139-143.
[3] Cerná, M.; Krsková, A.; Cejchanová, M.; Spěváčková, V. Human bio-monitoring in the Czech Republic: an overview. Int J Hyg Environ Health, 2012, 215(2), 109-119.

[4] National Committee for Clinical Laboratory Standards. Analytical procedures for the determination of lead in blood and urine; approved guideline. NCCLS document C40-A2001 NCCLS Wayne, PA.

[5] Apostoli, P.; Baj, A.; Bavazzano, P.; Ganzi, A.; Neri, G.; Ronchi, A.; Soleo, L.; Di, LL.; Spinelli, P.; Valente, T.; Minoia, C. Blood lead reference values: the results of an Italian polycentric study. Sci Total Environ, 2002, 287, 1-11.

(C) Valachova et al.; Licensee Bentham Open.

This is an open access article licensed under the terms of the Creative Commons Attribution Non-Commercial License (http://creativecommons.org/licenses/bync/3.0/), which permits unrestricted, non-commercial use, distribution and reproduction in any medium, provided the work is properly cited. 